\title{
RANCANGAN DESAIN FORMULIR MANUAL REKAM MEDIS BALAI PENGOBATAN GIGI DI PUSKESMAS KAHURIPAN KOTA TASIKMALAYA
}

\section{DESIGN OF MEDICAL RECORD MANUAL FORM DENTAL TREATMENT IN KAHURIPAN PUSKESMAS KOTA TASIKMALAYA}

\author{
Rieza Zulfahmi Taftazani ${ }^{1^{*}}$, Retno Hidayati ${ }^{2}$ \\ ${ }^{1}$ Jurusan Keperawatan Gigi, Poltekkes Kemenkes Tasikmalaya, ${ }^{2}$ Poltekkes Kemenkes \\ Tasikmalaya \\ *eza.exact@gmail.com
}

Kata kunci:

desain formulir rekam medis

rancangan formulir

rekam medis kedokteran gigi

Balai Pengobatan gigi

\section{ABSTRAK}

Formulir rekam medis merupakan sarana tempat pencatatan dari riwayat medis pasien, setiap dokter atau dokter gigi dalam menjalankan praktek kedokteran wajib membuat rekam medis, namun diketahui bahwa di Puskesmas Kahuripan sudah menyediakan formulir rekam medis khusus untuk Balai Pengobatan (BP) gigi, namun belum disesuaikan dengan Panduan rekam medis kedokteran gigi kemenkes RI Tahun 2015 dan PERMENKES nomor 269 tahun 2008 tentang Rekam Medis. Tujuan dari penelitian ini adalah merancang kembali desain formulir manual rekam medis Balai Pengobatan Gigi di Puskesmas Kahuripan Kota Tasikmalaya tahun 2018. Metode penilitian ini menggunakan metode penelitian kualitatif. Subjek penelitian ini yaitu Petugas Rekam Medis, Dokter Gigi dan Perawat Gigi. Pengumpulan data dalam penelitian ini yaitu menggunakan pengamatan (observasi) dan studi dokumen. Hasil penelitian ini yaitu rancangan Formulir Rekam Medis Balai Pengobatan Gigi Puskesmas Kahuripan Kota Tasikmalaya yang sesuai dengan aspek anatomik, aspek fisik dan aspek isi. Isi item dari formulir ini mengacu pada kebutuhan pengguna serta pedoman Rekam Medis Kedokteran Gigi Kemenkes RI tahun 2015.

\section{ABSTRACT}

Key word:

design medical record form draft form dentistry medical record Dental Clinic
Medical record form that represents the place of medical records, every doctor or dentist in medical practice is required to make a medical record, not yet approved at Kahuripan Health Center. Republic of Indonesia Ministry of Health of 2015 and Ministry of Health Regulation number 269 of 2008 concerning Medical Records. The purpose of this study was to update the design of the Medical Records Manual for the Dental Treatment Center in Kahuripan Health Center in Tasikmalaya City in 2018. This research method uses qualitative research methods. The subjects of this study were Medical Record Officers, Dentists and Dental Nurses. Data collection in this study uses observations (studies) 
and study documents. The results of this study were the making of a Medical Record Form for the Dental Treatment Center for the Tasikmalaya City Health Center in accordance with the anatomical, physical and content aspects. Fill out the items in this form according to user needs as well as the record of the Indonesian Ministry of Health Dentistry Republic of Indonesia.

\section{PENDAHULUAN}

Puskesmas adalah fasilitas pelayanan kesehatan yang menyelenggarakan upaya kesehatan masyarakat dan upaya kesehatan perseorangan tingkat pertama dengan lebih mengutamakan upaya promotif dan preventif, untuk mencapai derajat kesehatan masyarakat yang setinggi-tingginya di wilayah kerjanya (Peraturan Menteri Kesehatan no 75 tahun 2014). Di puskesmas sendiri memiliki tersimpan catatan medis setiap pasien yang biasa disebut rekam medis.

Menurut Peraturan Menteri Kesehatan (Permenkes) no 269 tahun 2008 tentang rekam medis yang dimaksud rekam medis adalah berkas yang berisi catatan dan dokumen antara lain identitas pasien, hasil pemeriksaan, pengobatan yang telah diberikan, serta tindakan dan pelayanan lain yang telah diberikan kepada pasien. Catatan merupakan tulisan-tulisan yang dibuat oleh dokter atau dokter gigi mengenai tindakan-tindakan yang dilakukan kepada pasien dalam rangka palayanan kesehatan. Rekam medispun memiliki berbagai kegunaan, yaitu administrasi, medis, hukum, finansial, penelitian dan dokumentasi.

Menurut Undang-Undang Republik Indonesia (UU RI) No 29 tahun 2004 tentang Praktik Kedokteran/ Kedokteran gigi Pasal 46, setiap dokter atau dokter gigi dalam menjalankan praktek kedokteran wajib membuat rekam medis. Apabila dokter dan dokter gigi tidak membuat rekam medis akan mendapat Sanksi sesuai UU RI No 29 Tahun 2004 pasal 79: dipidana dengan pidana kurungan paling lama 1 (satu) tahun atau denda paling banyak Rp. 50.000.000,- (lima puluh juta rupiah) untuk setiap dokter dan dokter gigi yang dengan sengaja tidak membuat rekam medis sebagaimana dimaksud dalam pasal 46 ayat (1). Adapun isi rekam medis baik untuk pasien rawat jalan, pasien rawat inap, pasien gawat darurat maupun pasien dalam keadaan bencana sekurang kurangnya diatur pada Permenkes RI nomor 269/Menkes/Per/III/2008 Bab II pasal 3.

Menurut buku Panduan rekam Medis Kedokteran Gigi, Sub-Direktorat Pelayanan Kesehatan Gigi dan Mulut Direktorat Bina Upaya Kesehatan Dasar Kementrian Kesehatan RI 2015 diuraikan bahwa rekam medis pelayanan gigi pada fasilitas pelayanan kesehatan harus dituangkan dalam formulir rekam medis pelayanan pengobatan gigi. Adapun bagian utama formulir rekam medis pelayanan pengobatan gigi tersebut terdiri dari Identitas pasien, Odontogram, tabel perawatan, serta lampiran pelengkap/ penunjang.

Sesuai dengan Permenkes Nomor 269/MenKes/Per/III/2008, rekam medis memiliki beberapa manfaat. Manfaat tersebut dapat dirasakan apabila rekam medis diisi dengan baik, namun di Puskesmas tersebut setiap riwayat kesehatan pasien diisikan pada 1 buku register yang sama sehingga dapat dikatakan bahwa rekam medis disatukan untuk semua pasien. Hal ini menurunkan efisiensi waktu pencarian riwayat pasien terdahulu, sehingga akan lebih baik apabila rekam medis diisikan pada lembar formulir untuk setiap pasien. Melihat permasalahan yang telah dikemukakan diatas, maka penulis bermaksud untuk melakukan penelitian dengan judul "Rancangan Desain Formulir Manual Rekam Medis Balai Pengobatan Gigi di Puskesmas Kahuripan Kota Tasikmalaya". 


\section{METODE}

Jenis penelitian yang digunakan dalam penelitian ini adalah Research and Development $(\mathrm{RnD})$. Penelitian dan pengembangan atau Research and Development $(\mathrm{RnD})$ adalah sebuah strategi atau metode penelitian yang cukup ampuh memperbaiki praktik (Nana Syaodih Sukmadinata, 2006). Penelitian dan pengembangan merupakan suatu proses atau langkah-langkah untuk mengembangkan suatu produk baru atau menyempurnakan produk yang telah ada dan dapat dipertanggungjawabkan. Produk tersebut dapat berupa perangkat keras ataupun perangkat lunak. Perangkat keras misalnya buku, modul, alat bantu pembelajaran di kelas atau di laboratorium. Perangkat lunak meliputi program komputer pengolahan data, pembelajaran di kelas, perpustakaan atau laboratorium, model-model pendidikan, pembelajaran, pelatihan, bimbingan, evaluasi, manajemen, dan lain-lain.

Pada penelitian pengembangan ini mengacu pada prosedur penelitian pengembangan menurut Sugiyono yang disesuaikan dengan kebutuhan peneliti. Prosedur penelitian pengembangan menurut Sugiyono dapat dilihat pada Gambar 1.

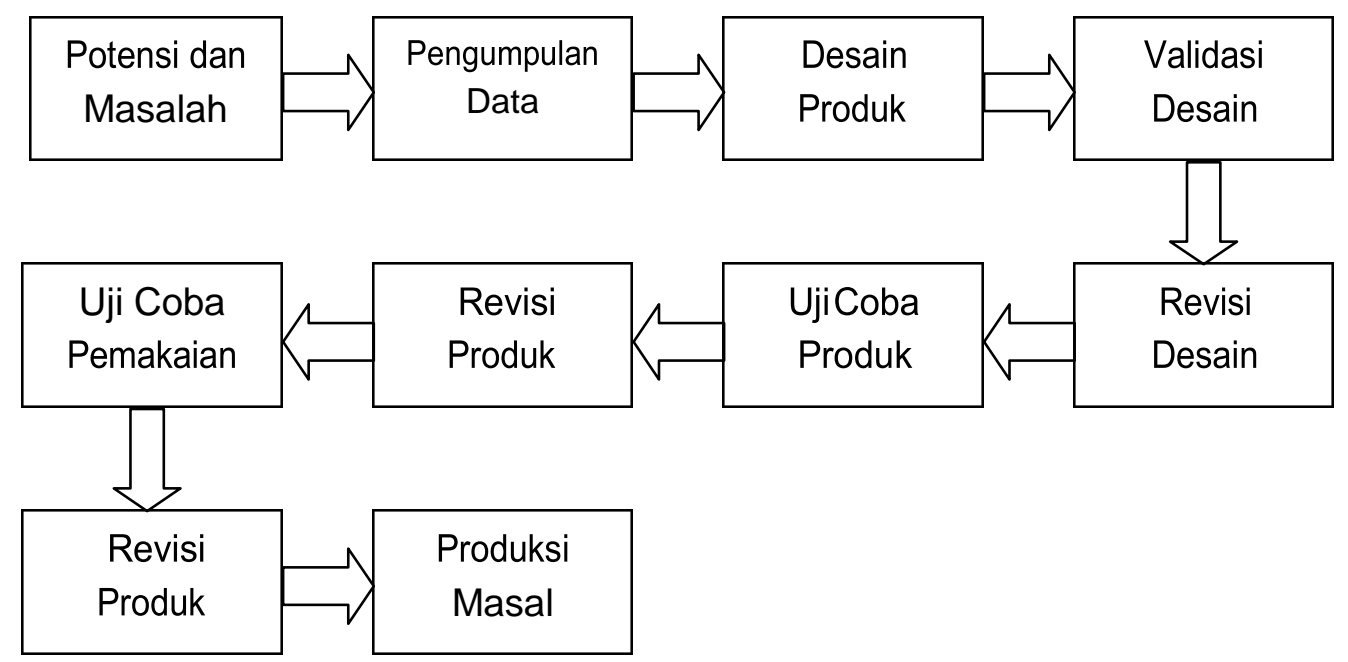

\section{Gambar 1. Prosedur Penelitian Pengembangan (Sugiyono, 2012)}

Penelitian kali ini peneliti hanya sebatas sampai tahap ke 5 (lima) yaitu Revisi desain produk. Produk yang telah didesain kemudian direvisi setelah diketahui kelemahannya, dikarenakan keterbatasannya waktu dan biaya. Subjek dalam penelitian ini adalah petugas yang berhubungan dengan formulir rekam medis balai pengobatan gigi di Puskesmas Kahuripan Kota Tasikmalaya, Informan yang akan dipilih adalah: 1) Dokter Gigi; 2) Perawat Gigi; 3) Petugas Rekam Medis

Pengumpulan data dilakukan dengan memakai metode sebagai berikut: Observasi penelitian dilakukan dengan mengamati secara langsung keadaan alur pasien serta rekam medis pasien khususnya pasien BP gigi. Observasi dilakukan juga untuk mengetahui secara langsung pendapat dari pengguna formulir rekam medis BP gigi. Pengumpulan data juga dilakukan dengan triangulasi data. Adapun triangulasi yang digunakan ini adalah triangulasi metode dan triangulasi sumber. Triangulasi metode ini menggunakan metode observasi dan studi dokumen, sedangkan triangulasi sumber menggunakan 3 sumber yang berbeda, yaitu kepala puskesmas, dokter gigi, dan perawat gigi. 


\section{HASIL DAN PEMBAHASAN}

Menurut hasil observasi yang telah dilakukan oleh peneliti, di Puskesmas Kahuripan Kota Tasikmalaya sudah ada formulir manual rekam medis BP gigi, namun belum sesuai dengan buku Panduan Rekam Medis Kedokteran Gigi Kementerian Kesehatan RI tahun 2015 yang menyatakan bahwa rekam medis pelayanan gigi pada fasilitas pelayanan kesehatan harus dituangkan dalam formulir rekam medis pelayanan pengobatan gigi. Melihat dari perihal tersebut, maka dapat diketahui bahwa Puskesmas Kahuripan Kota Tasikmalaya membutuhkan desain rekam medis BP gigi.

Menurut data yang telah diambil menggunakan instrumen ceklis, kebutuhan pengguna mengenai formulir adalah sebagai berikut:

Tabel 1. Kebutuhan Pengguna dalam Perancangan Formulir RM

\begin{tabular}{|c|c|c|}
\hline No & Perihal & Kebutuhan Pengguna \\
\hline 1 & Struktur Anatomik & $\begin{array}{ll}\text { - } & \text { Kepala (heading) } \\
\text { - } & \text { Perintah (instruction) } \\
\text { - } & \text { Isi (body) } \\
\text { - } & \text { Penutup (close) }\end{array}$ \\
\hline 2 & $\begin{array}{l}\text { Lembar berkas rekam } \\
\text { medis BP gigi }\end{array}$ & $\begin{array}{ll}\text { - Lembar identitas pasien } \\
\text { - } \\
\text { - Lembar odontogram } \\
\text { - } & \text { Lembar tabel perawatan lampiran pelengkap/ penunjang }\end{array}$ \\
\hline 3 & Bahan Formulir & Kertas dengan ketebalan seperti manila (160 gram) \\
\hline 4 & Bentuk & Persegi panjang \\
\hline 5 & Ukuran & A4 \\
\hline 6 & Warna & $\begin{array}{l}\text { Kertas biru (pria) } \\
\text { Kertas merah muda (wanita) } \\
\text { Tinta hitam }\end{array}$ \\
\hline 7 & Kemasan & Plastik Map \\
\hline 8 & $\begin{array}{l}\text { Kelengkapan item } \\
\text { mengenai identitas } \\
\text { pasien }\end{array}$ & $\begin{array}{ll}\text { - } & \text { Nomor Rekam Medis } \\
\text { - } & \text { Nama pasien } \\
\text { - } & \text { Jenis kelamin } \\
\text { - } & \text { Tanggal lahir } \\
\text { - } & \text { Pekerjaan } \\
\text { - } & \text { Suku bangsa } \\
\text { - } & \text { Alamat } \\
\text { - } & \text { Nomor HP } \\
\text { - } & \text { Golongan darah } \\
\text { - } & \text { Tekanan darah } \\
\text { - } & \text { Alergi terhadap obat } \\
\text { - } & \text { Riwayat penyakit } \\
\end{array}$ \\
\hline 9 & $\begin{array}{l}\text { Sedikit Informasi } \\
\text { mengenai pasien dalam } \\
\text { setiap formulir yang } \\
\text { dibutuhkan }\end{array}$ & $\begin{array}{ll}\text { - Nomor Rekam Medis } \\
\text { - Nama pasien }\end{array}$ \\
\hline 10 & $\begin{array}{l}\text { Kelengkapan item } \\
\text { mengenai perawatan } \\
\text { pasien }\end{array}$ & $\begin{array}{l}\text { - } \text { Tanggal dan waktu kunjungan } \\
\text { - Anamnesa } \\
\text { - Region } \\
\text { - } \text { Diagnosa } \\
\text { - Hasil Pemeriksaan fisik dan penunjang medis } \\
\text { - Diagnosis } \\
\text { - Pengobatan dan atau tindakan } \\
\text { - Nama dan tanda tangan }\end{array}$ \\
\hline
\end{tabular}


Home page: http://ejurnal.poltekkestasikmalaya.ac.id/index.php/jikg/index

\begin{tabular}{|c|c|c|}
\hline 11 & $\begin{array}{l}\text { Jenis odontogram yang } \\
\text { ingin diterapkan }\end{array}$ & 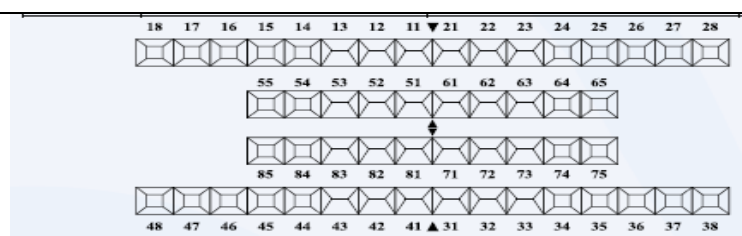 \\
\hline 12 & $\begin{array}{l}\text { Istilah, singkatan dan } \\
\text { simbol yang ingin } \\
\text { dimasukan ke dalam } \\
\text { formulir }\end{array}$ & Sesuaikan dengan pedoman yang ada \\
\hline
\end{tabular}

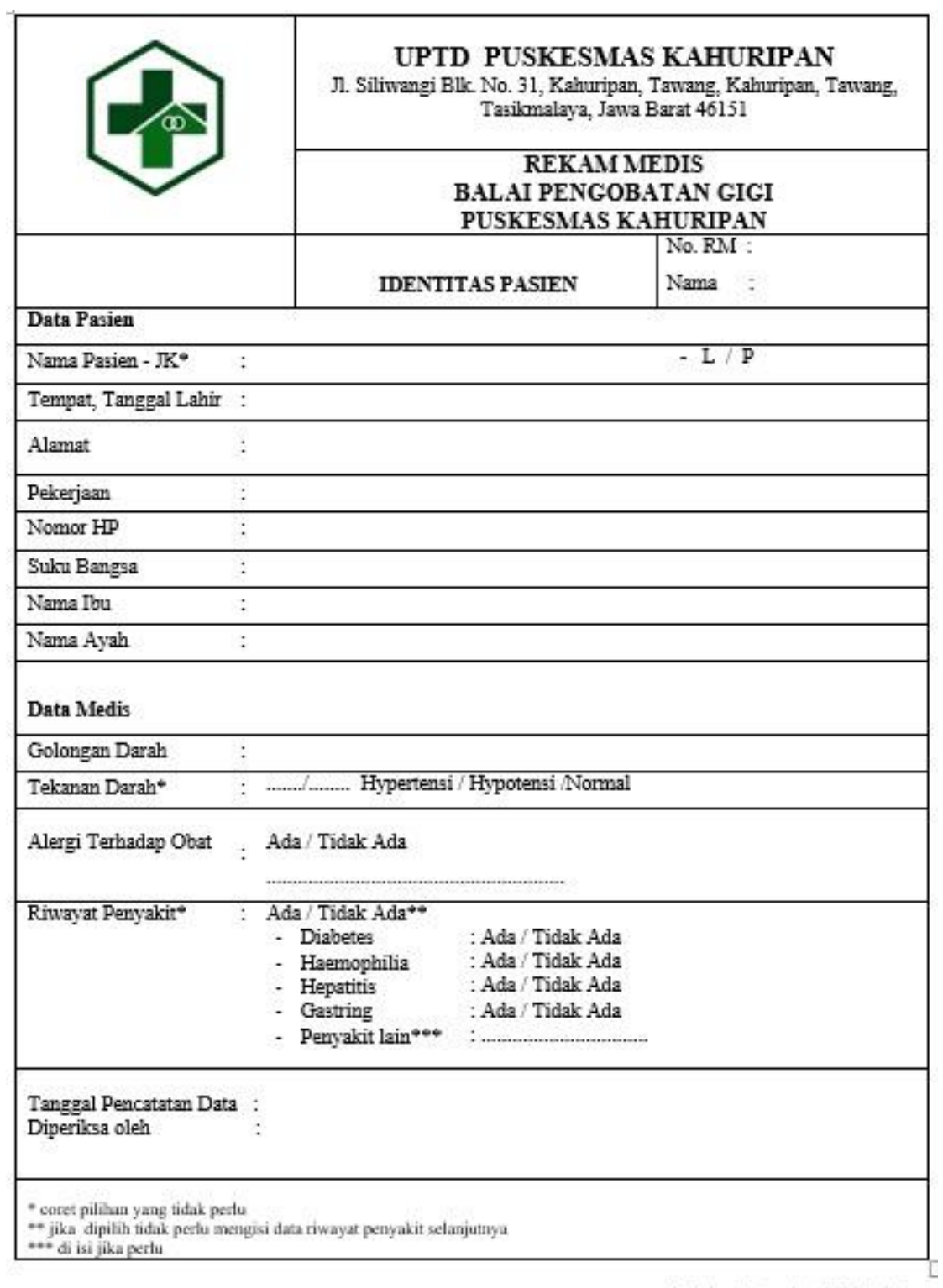

(Cotakian Sepotember 2013) Haf. I

Gambar 2. Lembar pertama formulir RM BP Gigi 

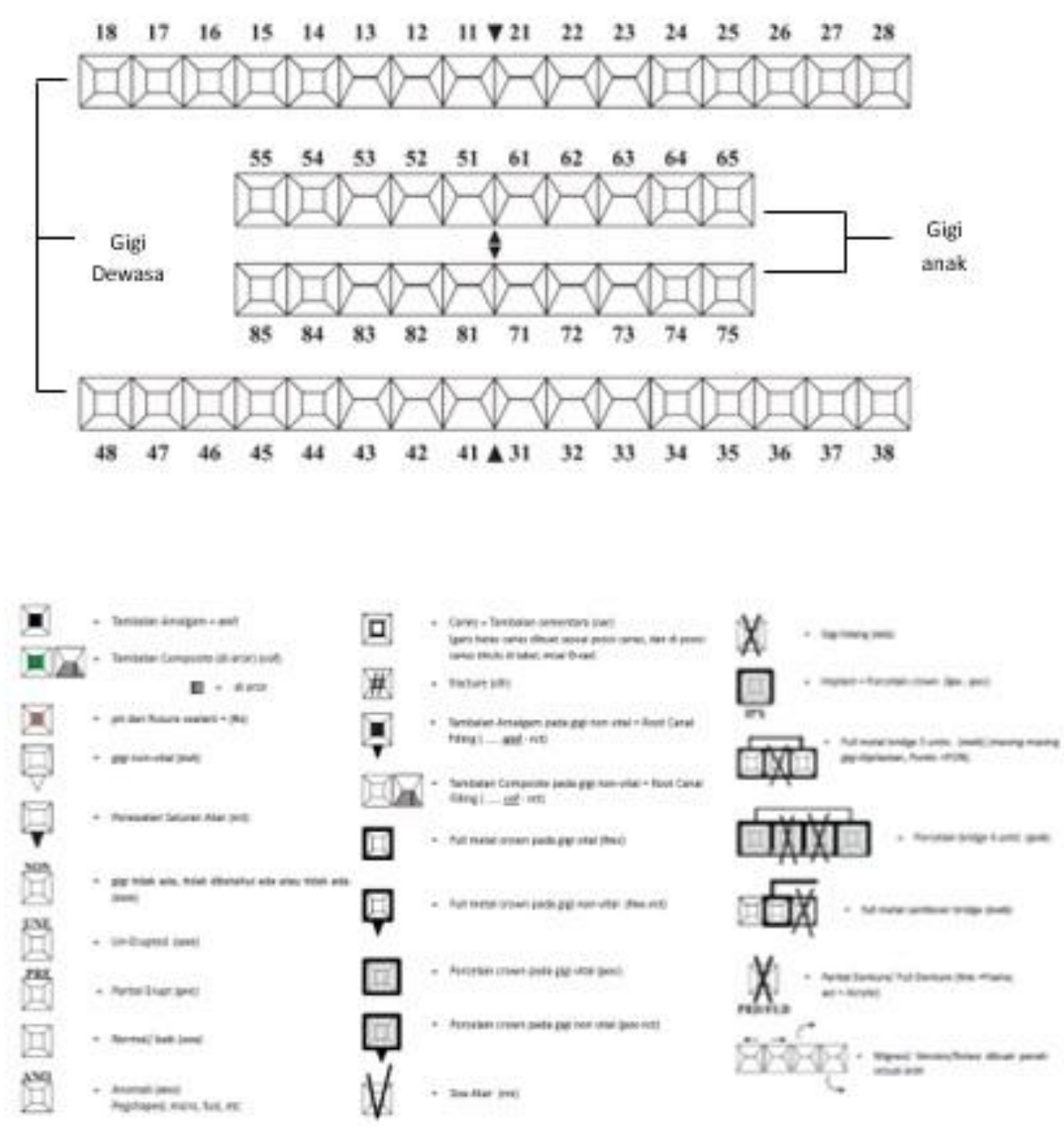

Odontogram di isi sesuai dengan simbol yang tersedia

Gambar 3. Lembar ke-2 formulir RM BP Gigi 
Home page: http://ejurnal.poltekkestasikmalaya.ac.id/index.php/jikg/index

No. RM :

Nama :

TABEL PERAWATAN PASIEN

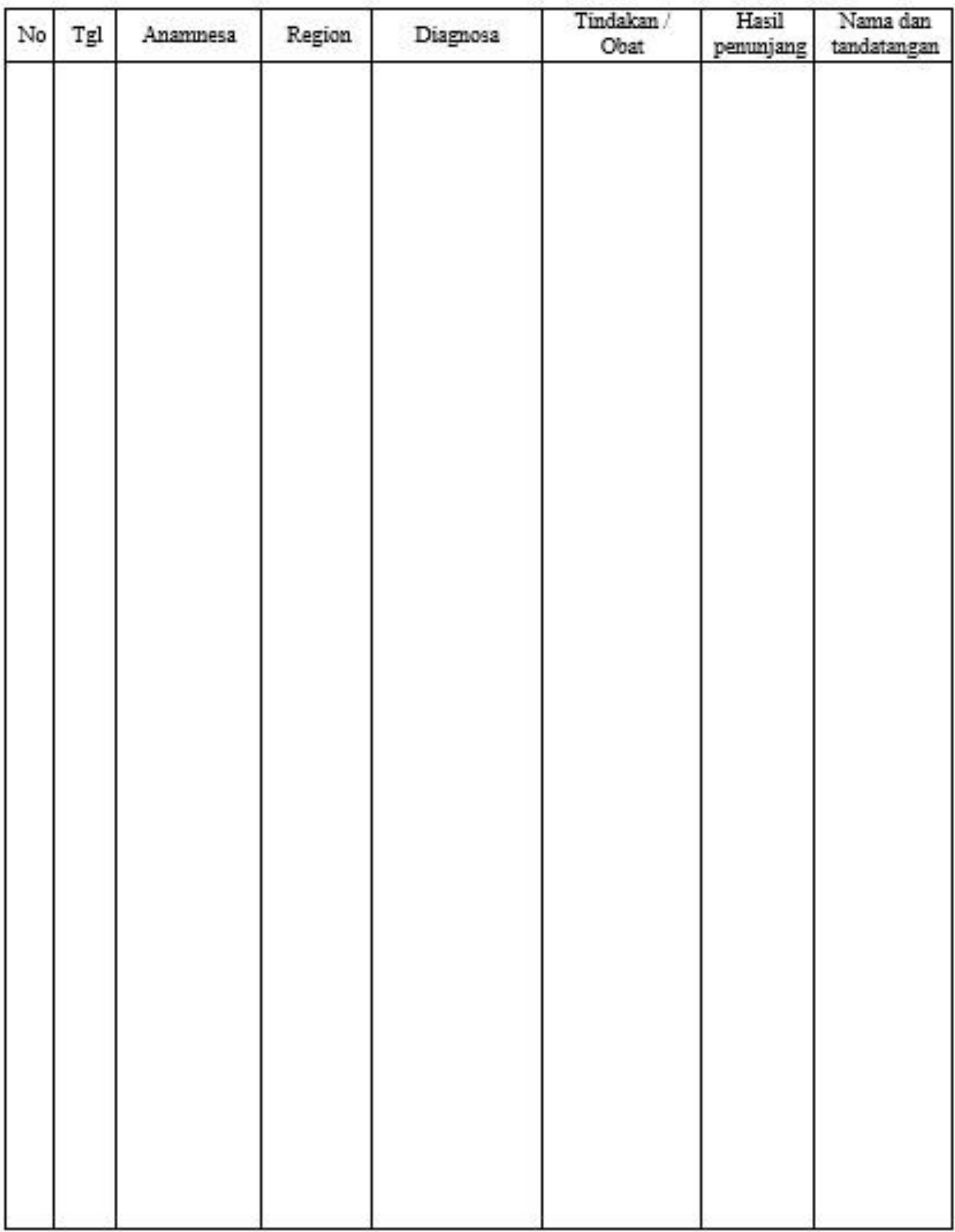

(Cotrokan Sepitember 2019) Hal, 3

Gambar 4. Lembar ke-3 formulir RM BP Gigi 
No. RM :

Nama

\section{LAMPIRAN PENUNJANG}

* lampiran di tempel menggunakan streples jika perlı.

Gambar 5. Lembar ke-4 formulir RM BP Gigi 


\section{KESIMPULAN}

Berdasarkan hasil penelitian tentang "Rancangan Desain Formulir Manual Rekam Medis Kedokteran Gigi di Puskesmas Kahuripan Kota Tasikmalaya", dapat disimpulkan sebagai berikut: 1) Sudah ada desain Formulir manual rekam medis Balai Pengobatan gigi dilihat dari aspek fisik, anatomik dan isi; 2) Telah dibuat rancangan ulang desain formulir manual rekam medis balai pengobatan gigi di Puskesmas Kahuripan Kota Tasikmalaya

\section{DAFTAR PUSTAKA}

Adawiyah, R. (2016). Rancangan Desain Formulir Rekam Medis Gawat Darurat Rumah Sakit Sumber Hurip. Karya Tulis Ilmiah. Cirebon : Poltekkes Kemenkes Tasikmalaya

Arikunto, S. (2010). Prosedur Penelitian Suatu Pendekatan Praktik. Jakarta : Rineka Cipta Budi, S. C. (2013). Bahan Ajar Pertemuan Ke-10 Desain Formulir Rekam Medis. Yogyakarta: Universitas Gajah Mada Sekolah Vokasi Diploma Rekam Medis

Budi, S. C. (2013). Bahan Ajar Pertemuan Ke-8 Desain Formulir Rekam Medis. Yogyakarta: Universitas Gajah Mada Sekolah Vokasi Diploma Rekam Medis

Budi, S. C. (2013). Bahan Ajar Pertemuan Ke-9 Desain Formulir Rekam Medis. Yogyakarta: Universitas Gajah Mada Sekolah Vokasi Diploma Rekam Medis

DepKes RI. (1995). Petunjuk Teknis Pengadaan Formulir Rekam Medis Dasar Dan Pemusnahan Asrip Rekam Medis. Jakarta : Direktorat Jenderal Bina Yanmed

Diana. (2012). Odontograma Image. 13 februai 2017. www.clker.com/clipart-202462.html

Direktorat Bina Upaya Kesehatan Dasar Kementrian Kesehatan RI. (2014). Panduan Rekam Medis Kedokteran Gigi. Jakarta : Kementrian Kesehatan RI

Direktorat Bina Upaya Kesehatan Dasar Kementrian Kesehatan RI. (2015). Panduan Rekam Medis Kedokteran Gigi. Jakarta : Author / Kementrian Kesehatan RI

Direktorat Jenderal Bina Pelayanan Medik Departemen Kesehatan RI. (2007). Standar Nasional Rekam Medik Kedokteran Gigi. Jakarta: Departemen Kesehatan RI

Direktur Jenderal Pelayanan Medis. (1997). Pedoman Pengelolaan Rekam Medis Rumah Sakit Indonesia. Jakarta :UI-Press

Hatta, G. R. (2013). Pedoman Manajemen Informasi Kesehatan disarana Pelayanan Kesehatan. Jakarta : UI

Karimah, R. N., Nurmawati,Ida. (2016). jurnal Perancangan Berkas Rekam Medis Kedokteran Gigi di Klinik Sakinah Kabupaten Jember. 29 Januari 2017.

Kementrian Kesehatan RI. (2008). Peraturan Menteri Kesehatan Repubik Indonesia nomor 269/Menkes/Per/III/2008 Tentang Rekam Medis. Jakarta.

Notoadmojo, S. (2010). Metodologi Penelitian Kesehatan. Jakarta : PT Asdi Mahasaya

Saryono, anggraeni, mekar dwi. (2010). Metodologi penelitian kualititaif dalam bidang kesehatan. Yogyakarta : Nuha Medika

Sugiyono. (2013). Metode Penelitian Kuantitatif Kualitatif dan $R \&$ D. Bandung : Alfabeta

Surat Edaran Direktorat Jenderal Pelayanan Medis Republik Indonesia Nomor HK 00.06.1.5.01160 tahun 1995

Undang-Undang Nomor 29 Tahun 2004 Tentang Praktik Kedokteran Pasal 46 